\title{
Determinan Pelaksanaan Inisiasi Menyusu Dini
}

\section{Determinant of the Implementation Early Breastfeeding Initiation}

\author{
Saifuddin Sirajuddin* Tahir Abdullah** Sutriyani N Lumula****
}

\begin{abstract}
*Program Studi Gizi Fakultas Kesehatan Masyarakat Universitas Hasanuddin, **Program Studi Magister Fakultas Kesehatan Masyarakat Universitas Hasanuddin, ***Dinas Kesehatan Kabupaten Boalemo
\end{abstract}

\begin{abstract}
Abstrak
Inisiasi Menyusu Dini (IMD) adalah salah satu program Departemen Kesehatan Republik Indonesia, yang memberikan rangsangan awal dimulai pemberian Air Susu Ibu (ASI) secara dini, dan diharapkan berkelanjutan selama enam bulan pertama. Kegagalan IMD dan pemberian ASI eksklusif pada periode tersebut, berpotensi menimbulkan defisiensi zat gizi pada bayi, serta memungkinkan terjadi status gizi kurang, yang berujung pada penurunan poin kecerdasan intelektual bayi, dan menjadi ancaman terhadap sumber daya manusia Indonesia peda masa mendatang. Penelitian ini bertujuan mengetahui pengaruh faktor determinan pendidikan, pengetahuan, sikap ibu, tindakan bidan dan dukungan keluarga) terhadap Pelaksanaan IMD. Desain penelitian yang digunakan adalah potong lintang, populasi adalah ibu yang bersalin di Puskesmas Tilamuta, Kabupaten Boalemo. Sampel sebanyak 215 orang ditentukan secara acak sederhana. Analisis data dilakukan secara univariat, bivariat dengan uji kai kuadrat dan analisis multivariat dengan regresi linier ganda. Hasil penelitian menunjukkan bahwa terdapat tiga variabel yang berkontribus meliputi dukungan keluarga, pendidikan, tindakan bidan (nilai $p<0,05$ ). Variabel dukungan keluarga, pendidikan dan tindakan bidan adalah determinan penting, sedangkan variabel dukungan keluarga adalah determinan utama terhadap pelaksanaan IMD.

Kata kunci: Bidan, dukungan keluarga, inisiasi menyusu dini
\end{abstract}

\footnotetext{
Abstract

Early Breastfeeding Initiation (IMD) is Indonesian's Ministry of Health program, which is intended to provide early stimulation start of breastfeeding, and expected to sustained during the first six months (exclusive breastfeeding). IMD failure and exclusive breastfeeding during this period, potentially causing nutrient deficiency in infants, and allow the malnutrition status, which led to the decline of infant IQ points, and a threat to Indonesia's human resource in the future. This study aims to determine the determinant factors (education, knowledge, attitude mother, midwife, and family support
}

measures) of implementation of IMD. The study design was cross sectional study, population was mothers who delivered at health centersTilamuta, Boalemo district. Sample as many as 215 drawn by simple random sampling. Data analysis was performed using univariate, bivariate by chi square test and multivariate analysis using multiple logistic regression. The results of the study showed that there were a relation between education, knowledge, mother attitude, midwife action, and family support with the implementation of IMD ( $p$ value < 0.05 ). Multivariate analysis showed that variable family support, education, and midwife action contribute to the implementation of the IMD ( $p$ value < 0.05 ), and family support give the highest contribution. Family support, education and midwife action are an important determinant, whereas family support is the main determinants of the implementation of IMD.

Keywords: Midwife, family support, early breastfeeding initiation

\section{Pendahuluan}

Inisiasi Menyusu Dini (IMD) adalah suatu upaya mengembalikan hak bayi yang selama ini terenggut oleh para praktisi kelahiran yang membantu proses persalinan yang langsung memisahkan bayi dari ibu sesaat setelah dilahirkan. Langkah ini tidak membuat bayi menjadi lebih baik, tetapi justru menurunkan ketahanan tubuh bayi hingga 25 persen. Pada kasus yang lebih parah, bayi dapat mengalami goncangan psikologis akibat kehilangan perlindungan yang ia butuhkan dari ibu sehingga berdampak buruk terhadap tumbuh kembang, khususnya kualitas fisik, psikologis, dan kecerdasan anak. Bayi tersebut berpotensi mengalami keterbelakangan kognitif

Alamat Korespondensi: Saifuddin Sirajuddin, Program Studi Gizi FKM Universitas Hasanuddin, Jl. Perintis Kemerdekaan Km. 10 Tamalanrea Makassar 90245, Hp.085399796462, e-mail: saifuddin59@yahoo.com 
yang dinilai melalui poin kecerdasan intelektual. Penurunan poin kecerdasan intelektual sebesar 15\% akan menjadi ancaman bagi kualitas Sumber Daya Manusia (SDM) di kemudian hari. Dengan pemahaman dan pelaksanaan yang baik tentang IMD, seorang ibu telah meletakkan dasar yang baik dan kuat bagi tumbuh kembang anak. Pemenuhan Air Susu Ibu (ASI) yang dilakukan sejak bayi lahir sampai usia 6 bulan berdampak pada poin kecerdasan intelektual yang lebih tinggi, yaitu 12,9 pada usia 9 tahun. ${ }^{1}$

IMD bukan saja menyukseskan pemberian ASI eksklusif, tetapi lebih dari itu memperlihatkan hasil nyata menyelamatkan nyawa bayi. Apabila semua bayi segera setelah lahir diberi kesempatan menyusu sendiri dengan membiarkan kontak kulit ibu ke kulit bayi paling tidak selama satu tahun, maka satu juta nyawa bayi dapat diselamatkan. ${ }^{1}$ Hasil penelitian menunjukkan bahwa IMD dapat mengurangi Angka Kematian Neonatal sebesar $22 \%$. Di berbagai negara berkembang IMD dapat menghemat sekitar 1,45 juta jiwa setiap tahun. Berdasarkan hasil penelitian di Bolivia dan Madagaskar, seperempat sampai setengah dari kematian bayi di negara berkembang terjadi pada minggu pertama kehidupan. ${ }^{2}$ Berbagai penelitian telah mengkaji manfaat pemberian ASI eksklusif sebagai upaya menurunkan mortalitas bayi, menurunkan morbiditas bayi, mengoptimalkan pertumbuhan bayi, membantu perkembangan kecerdasan anak, dan membantu memperpanjang jarak kehamilan. 3,4

Penelitian di Negara Timur Tengah menemukan hanya $6 \%$ ibu menyusu pada lima jam pertama kelahiran, $71,6 \% 36$ jam setelah kelahiran dan sebagian besar $(90 \%)$ dua hari setelah kelahiran. ${ }^{3}$ IMD tertunda yang tinggi sangat dipengaruhi oleh pengetahuan, serta budaya. Data UNICEF menunjukkan bahwa angka cakupan praktik IMD di Indonesia dari tahun 2003 hingga 2008 sebesar 39\% dan cakupan ASI eksklusif enam bulan sebesar 40\%. ${ }^{5}$ Sementara itu, hasil Riskesdas menunjukkan persentase IMD sebesar 29,3\%, lebih rendah dari tahun $2008 .^{6}$

Berbagai faktor yang menyebabkan praktik IMD di Indonesia rendah antara lain adalah tingkat pendidikan, sikap, dan motivasi ibu menyusu yang kurang dipengaruhi oleh perilaku dan tindakan bidan serta dukungan keluarga. ${ }^{7}$ Penelitian ini bertujuan untuk mengetahui faktor determinan pendidikan, pengetahuan, sikap ibu, tindakan bidan, dan dukungan keluarga terhadap pelaksanaan IMD di Wilayah Kerja Puskesmas Tilamuta Kabupaten Boalemo, Provinsi Gorontalo.

\section{Metode}

Penelitian dilaksanakan di wilayah kerja Puskesmas Tilamuta Kabupaten Boalemo, Provinsi Gorontalo yang lokasinya terletak di wilayah yang tidak terlalu jauh dari pusat kota. Sebagian besar dihubungkan dengan trans- portasi darat yang cukup lancar. Penelitian observasional analitis ini menggunakan desain studi potong lintang. Populasi penelitian adalah ibu bersalin di wilayah kerja Puskesmas Tilamuta pada periode bulan Januari hingga Desember 2012. Sampel sebanyak 215 orang yang dipilih secara acak sederhana. Pengumpulan dilakukan langsung pada responden melalui wawancara dengan menggunakan kuesioner. Metode wawancara ini dilakukan pada saat kegiatan posyandu dan kunjungan ke tiap rumah bagi ibu yang berhalangan hadir di posyandu. Analisis data secara univariat dilakukan terhadap semua variabel penelitian. Untuk melihat hubungan variabel independen dengan variabel dependen (bivariat), analisis kai kuadrat digunakan untuk melihat variabel independen yang paling berpengaruh terhadap variabel dependen digunakan uji regresi logistik berganda.

\section{Hasil}

Sebagian besar responden berada pada usia reproduksi sehat (20 - 34 tahun), tetapi tingkat pendidikan responden sebagian besar masih tergolong rendah meliputi SD dan SMP dan umumnya bekerja sebagai ibu rumah tangga. IMD lebih banyak dilaksanakan pada ibu yang berpendidikan cukup $(69,6 \%)$ daripada yang berpendidikan kurang $(23,1 \%)$ (Tabel 1).

Pengaruh pendidikan terhadap pelaksanaan IMD (nilai $\mathrm{p}=0,000$ ) dan berkontribusi sekitar $37,1 \%$ atau tingkat kekuatan hubungannya sedang. Pelaksanaan IMD lebih banyak dilaksanakan pada ibu yang mempunyai pengetahuan yang cukup $(66,3 \%)$ dibandingkan ibu yang mempunyai pengetahuan kurang $(37,8 \%)$. Ditemukan pengaruh pengetahuan terhadap pelaksanaan IMD (nilai $\mathrm{p}=0,000$ ) dengan kontribusi hanya 22,1\% (lemah). Sikap ibu juga menunjukkan pengaruh yang bermakna terhadap pelaksanaan IMD (nilai $\mathrm{p}=0,002$ ), pelaksanaan IMD lebih banyak dilaksanakan oleh ibu yang mempunyai sikap yang mendukung $(66,9 \%)$ dibandingkan ibu yang mempunyai sikap tidak mendukung $(42,9 \%)$,

Tabel 1. Distribusi Berdasarkan Karakterisitik Responden

\begin{tabular}{llll}
\hline Karakteristik & Kategori & $\mathbf{n}$ & $\%$ \\
\hline Kelompok usia (tahun) & $\leq 19$ & 15 & 7,0 \\
& $20-24$ & 57 & 26,5 \\
& $25-29$ & 79 & 36,7 \\
& $30-34$ & 54 & 25,1 \\
& $35-39$ & 9 & 4,2 \\
Pendidikan & $\geq 40$ & 1 & 0,5 \\
& $<$ SD & 118 & 54,9 \\
& SLTP & 63 & 9,3 \\
& SLTA & 29 & 13,5 \\
Jenis pekerjaan & Diploma & 1 & 0,5 \\
& Perguruan tinggi & 4 & 1,9 \\
& Ibu rumah tangga & 207 & 96,3 \\
& Swasta & 1 & 0,5 \\
& PNS & 7 & 3,3 \\
\hline
\end{tabular}


Tabel 2. Distribusi Faktor yang Berhubungan Pelaksanaan Inisiasi Menyusu Dini

\begin{tabular}{|c|c|c|c|c|c|c|c|}
\hline \multirow{3}{*}{ Variabel } & \multirow{3}{*}{ Kategori } & \multicolumn{4}{|c|}{ Pelaksanaan Inisiasi Menyusu Dini } & \multirow{3}{*}{ Nilai p } & \multirow{3}{*}{ Nilai Phi } \\
\hline & & \multicolumn{2}{|c|}{ Tidak } & \multicolumn{2}{|c|}{ Ya } & & \\
\hline & & $\mathbf{n}$ & $\%$ & $\mathbf{n}$ & $\%$ & & \\
\hline \multirow[t]{2}{*}{ Pendidikan } & Kurang & 30 & 76,9 & 9 & 23,1 & 0,000 & 0,371 \\
\hline & Cukup & 53 & 30,1 & 123 & 69,9 & & \\
\hline \multirow[t]{2}{*}{ Pengetahuan } & Kurang & 23 & 63,3 & 14 & 37,8 & 0,001 & 0,221 \\
\hline & Cukup & 60 & 33,7 & 118 & 66,3 & & \\
\hline \multirow[t]{2}{*}{ Sikap ibu } & Tidak mendukung & 28 & 57,1 & 21 & 42,9 & 0,002 & 0,207 \\
\hline & Mendukung & 55 & 33,1 & 111 & 66,9 & & \\
\hline \multirow[t]{2}{*}{ Tindakan bidan } & Tidak dilakukan & 56 & 66,7 & 28 & 33,3 & 0,000 & 0,462 \\
\hline & Dilakukan & 55 & 33,1 & 111 & 66,9 & & \\
\hline \multirow[t]{2}{*}{ Dukungan keluarga } & Tidak ada & 64 & 69,6 & 28 & 30,4 & 0,000 & 0,550 \\
\hline & Ada & 19 & 15,4 & 104 & 84,6 & & \\
\hline
\end{tabular}

Tabel 3. Analisis Multivariat Determinan Pelaksanaan Inisiasi Menyusu Dini

\begin{tabular}{lllllll}
\hline Variabel & B & Wald & Df & Nilai p & OR & 95\% CI \\
\hline Dukungan keluarga & 1,914 & 21,969 & 1 & 0,000 & 6,783 & $3,046-15,103$ \\
Pendidikan & 1,780 & 13,669 & 1 & 0,000 & 5,932 & $2,308-15,245$ \\
Tindakan bidan & 0,945 & 5,400 & 1 & 0,020 & 2,573 & $1,159-5,711$ \\
\hline
\end{tabular}

besarnya kontribusi variabel sikap terhadap pelaksanaan IMD berdasarkan uji Phi $=20,7 \%$. Tindakan bidan dan dukungan keluarga berpengaruh bermakna terhadap pelaksanaan IMD (nilai $\mathrm{p}=0,000$ ) dan berkontribusi yang lebih besar terhadap pelaksanaan IMD, masingmasing adalah $46,2 \%$ dan 55,0\% (Tabel 2).

Hasil analisis multivariat uji regresi logistik menunjukkan bahwa dari lima variabel penelitian hanya tiga variabel yang memberikan kontribusi yang bermakna (nilai $\mathrm{p}<0,05$ ), yaitu dukungan keluarga , pendidikan ibu dan tindakan bidan. Berdasarkan hasil tersebut terlihat bahwa variabel yang berkontribusi paling besar adalah dukungan keluarga (Tabel 3).

\section{Pembahasan}

Penelitian ini terfokus pada penilaian hubungan faktor determinan yang berkontribusi terhadap pelaksanaan IMD di wilayah kerja Puskesmas Tilamuta Kabupaten Boalemo Provinsi Gorontalo meliputi pendidikan, pengetahuan, sikap ibu, tindakan bidan, dan dukungan keluarga. Secara teori, lima variabel ini dianggap berkontribusi signifikan terhadap pelaksanaan IMD, sesuai dengan hasil analisis bivariat. Namun, berdasarkan hasil analisis multivariat yang melihat pengaruh variabel independen secara serentak terhadap variabel dependen, hanya variabel dukungan keluarga, pendidikan, dan tindakan bidan yang berpengaruh terhadap pelaksanaan IMD.

Disadari bahwa ibu yang berpengetahuan cukup berpeluang besar untuk melakukan suatu pekerjaan, tetapi hal tersebut belum menjamin ibu mengambil keputusan. Salah satu penyebabnya adalah pengaruh situasi dan kondisi ibu yang masih kelelahan dalam menjalani proses persalinan sehingga proses IMD tidak dilaksanakan. Demikian juga dengan sikap, diantaranya pada saat proses persalinan ibu tidak didampingi keluarga, sehingga motivasi dari ibu itu sendiri kurang, apalagi tidak dibarengi dengan pengetahuan yang cukup tentang manfaat IMD. 8

Besar kontribusi dukungan keluarga terhadap pelaksanaan IMD yang dinilai melalui uji Phi $=0,550$ atau $55,0 \%$. Demikian juga dengan uji multivariat dengan menggunakan regresi logistik memperlihatkan nilai nilai $\mathrm{p}=0,000$, dengan besar pengaruh dukungan keluarga $\mathrm{OR}=6,78$. Hal tersebut berarti ibu yang mendapatkan dukungan keluarga berpeluang 6,8 kali lebih besar melakukan IMD dibandingkan dengan ibu yang tidak mendapatkan dukungan dari keluarga. Hasil penelitian ini sejalan dengan penelitian sebelumnya yang membuktikan bahwa responden yang mendapatkan dukungan keluarga, sekitar 77,8\% menyatakan bahwa mereka berhasil melakukan IMD. ${ }^{9}$ Pelaksanaan IMD sangat memerlukan dukungan suami ataupun keluarga. Penelitian di Kuwait menunjukkan bahwa, pemberian ASI berhubungan positif dengan dukungan keluarga dan berhubungan negatif dengan persalinan sesar. ${ }^{10}$ Kondisi emosi yang stabil menentukan sikap ibu yang positif. Kestabilan emosi tersebut dapat diraih apabila suami atau keluarga memberikan dukungan dan motivasi secara maksimal. Dukungan memberikan suatu kesan bahwa ia dicintai dan diperhatikan, memiliki harga diri dan dihargai sehingga dengan sendirinya akan berpengaruh terhadap emosional. Ibu lebih tenang, nyaman, dan percaya diri dalam melakukan 
proses IMD pada bayi. ${ }^{11}$

Proses menyusu bayi melibatkan tiga hubungan insani. Ibu yang memberikan ASI, si anak yang diberikan ASI dan suami/keluarga sebagai penyeimbang hubungan. Namun, banyak kaum suami dan keluarga yang merasa tidak terlibat dalam proses sosial ini dan cenderung menyerahkan segala urusan pemberian ASI pada ibu saja, serta merasa tidak perlu ikut campur dalam proses tersebut. Keterlibatan seorang suami dalam pelaksanaan IMD ini akan memotivasi ibu untuk menyusu. Jika ibu sudah memiliki motivasi dan optimis dapat menyusu, air susu pun akan berhamburan. ${ }^{12}$ Ibu yang mendapatkan dukungan keluarga dalam proses persalinan, sekitar 31,4\% memberikan sikap positif terhadap pelaksanaan IMD.

Penelitian ini juga menemukan bahwa pendidikan berhubungan dengan pelaksanaan IMD, sesuai dengan hasil uji statistik yang menunjukkan besarnya kontribusi tingkat pendidikan terhadap pelaksanaan IMD yang dinilai melalui uji Phi $=29,51$ atau 29,5\%. Demikian juga dengan uji multivariat dengan menggunakan regresi logistik memperlihatkan nilai $\mathrm{p}=0,000$, dengan besar pengaruh pendidikan $\mathrm{OR}=5,93$. Hal tersebut berarti pendidikan yang cukup berpengaruh 5,9 kali lebih besar terhadap pelaksanaan IMD dibandingkan dengan ibu yang berpendidikan kurang. Semakin tinggi pendidikan seseorang, semakin tinggi juga daya penalaran terhadap setiap informasi yang diberikan sehingga lebih mudah untuk melakukan tindakan.

Beberapa hasil penelitian menemukan bahwa frekuensi menyusu dini lebih tinggi diantara wanita terpelajar. ${ }^{13}$ Ibu yang terpelajar menyadari keuntungan fisiologi dan psikologis dari menyusu, ibu terpelajar lebih termotivasi memiliki kesempatan lebih banyak untuk mendapat informasi serta mempunyai fasilitas yang lebih baik. Selanjutnya penelitian oleh Setegndi Ethiopia, ${ }^{14}$ menunjukkan bahwa ibu yang memiliki pendidikan formal berpeluang $1-4$ kali lebih besar untuk memulai menyusu pada satu jam pertama dibandingkan yang tidak memiliki pendidikan formal. Penelitian lain menemukan bahwa ada hubungan yang bermakna antara pendidikan dengan pemberian ASI dini, responden yang berpendidikan tinggi melakukan IMD 74,7\% dibandingkan dengan responden berpendidikan rendah. ${ }^{15}$

Penelitian ini juga menemukan bahwa tindakan bidan berhubungan dengan pelaksanaan IMD oleh ibu bersalin. Hasil analisis statistik menunjukkan besar kontribusi tindakan bidan terhadap pelaksanaan IMD adalah $46,2 \%$. Hasil analisis multivariat menunjukkan nilai $\mathrm{OR}=2,57$, berarti tindakan bidan berpengaruh 2,6 kali lebih besar terhadap pelaksanaan IMD dibandingkan dengan bidan yang tidak melakukan tindakan. Hal ini bisa dipahami, karena bidan merupakan orang yang pertama dan utama dalam menentukan keberhasilan pelaksanaan IMD. Frekuensi kontak antara ibu dan bidan lebih sering di- bandingkan dengan tenaga kesehatan yang lain sehingga peran bidan dalam memberikan informasi, konseling, serta tindakan yang nyata sangat menentukkan keberhasilan pelaksanaan IMD. Tindakan nyata bidan memberi kesan terhadap ibu dan keluarga, bahwa kegiatan IMD ini benar-benar bermanfaat untuk ibu dan bayi. Di salah satu rumah sakit pusat rujukan di Jakarta Pusat, ditemukan hubungan signifikan antara tindakan bidan dengan pelaksanaan IMD. Tindakan bidan akan memberi peluang yang besar kepada ibu untuk melakukan IMD pada bayi. Tindakan tersebut berupa membantu melaksanakan IMD, dan tidak memberikan susu botol atau susu formula kepada bayi. ${ }^{16}$ Di Ghana, perhatian yang diberikan oleh petugas kesehatan yang membatu persalinan sangat menentukan pelaksanaan IMD dan kebutuhan dibuat kebijakan meningkatkan perhatian masyarakat untuk melaksanakan IMD. ${ }^{17}$ Pemberian ASI dalam jangka satu jam setelah melahirkan akan meningkatkan ikatan antara ibu dan anak. ${ }^{18}$

\section{Kesimpulan}

Pendidikan, pengetahuan, sikap, tindakan bidan, dan dukungan keluarga berpengaruh terhadap pelaksanaan IMD secara signifikan. Variabel dukungan keluarga merupakan variabel yang berkontribusi paling besar kontribusinya terhadap pelaksanaan IMD, diikuti oleh pendidikan ibu dan tindakan bidan.

\section{Saran}

Kepada petugas kesehatan khususnya bidan agar lebih intensif lagi melakukan konseling dan penyuluhan tentang kepentingan pelaksanaan IMD pada ibu hamil dan keluarga. Selain itu, melakukan tindakan IMD sesuai prosedur pada ibu pascasalin, lebih meningkatkan kesadaran keluarga, terutama suami agar senantiasa mendukung ibu bersalin sejak ibu hamil, pendampingan pada saat proses persalinan sehingga proses pelaksanaan IMD terlaksana dengan baik.

\section{Daftar Pustaka}

1. Roesli U. Inisiasi menyusu dini plus ASI ekslusif. Jakarta: Pustaka Bunda; 2008.

2. Baker EJ, Sanei LC, Franklin N. Early initiation of and exclusive breastfeeding in large-scale community-based programmes in Bolivia and Madagascar. Journal of Health, Population, and Nutrition. 2006; 24 (4): 530-9.

3. Edmond KM, Zandoh C, Quigley MA, Amenga- Etego S, Owusu-Agyei $\mathrm{S}$, Kirkwood BR. Delayed breastfeeding initiation increases risk of neonatal mortality. Journal of Pediatrics. 2006; 117(3): e380-6.

4. Sacker A, Quigley MA, Kelly YJ. Breastfeeding and developmental delay: Findings from the millennium cohort study. Journal of Pediatrics. 2006; 118(3): e682-9.

5. World Health Organization United Nations Children's Fund. Melindungi meningkatkan dan mendukung menyusu. Jakarta: Rineka Cipta Peri- 
nerasia; 2009.

6. Badan Penelitian dan Pengembangan Kesehatan Kementerian Kesehatan Republik Indonesia. Laporan Riset Kesehatan Dasar (Riskesdas) tahun 2010. Jakarta: Badan Penelitian dan Pengembangan Kesehatan Kementerian Kesehatan Republik Indonesia; 2010.

7. Margawati A. Patterns of breast-feeding practice in Semarang Indonesia comparison between women in veri-urban area and urban area [cited 2013 Jun 6]. Available from: https://hydra.hull.ac.uk/resources/hull:6006.

8. Hidayat KA, Dewantiningrum J. Perbandingan pelaksanaan IMD berdasarkan tingkat pengetahuan ibu hamil. Jurnal Media Medika Universitas Diponegoro. 2012.

9. Suryana DN, Mularsih S. Dukungan suami dengan pelaksanaan inisiasi menyusu dini pada ibu post partum di BPS Kota Semarang. Dinamika Kebidanan. 2011; 1 (1).

10. Dashti M, Scott JA, Edwards CA. Determinants of breastfeeding initiation among mothers in Kuwait. Int breastfeed J [serial on internet]. 2010 [cited 2013 Jan 23]; 5:7. Available from: www. International Breastfeeding Journal.com.

11. Mannion CA, Hobbs AJ, McDonald SW, Tough SC. Maternal perceptions of partner support during breastfeeding. Int Breastfeed J [serial on internet]. 2013 [cited 2013 Jul 4]; 8: 4. Available from: www. International Breastfeeding Journal.com
12. Paramita. Dukungan keluarga [diakses tanggal 26 November 2012] Diunduh dalam: http://www.rajawana.com/artikel/kesehatan/435dukungan-keluarga.html.

13. Amalia. Analisis sosialisasi program inisiasi menyusu dini dan ASI ekslusif kepada bidan di kabupaten Klaten [diakses tanggal 5 Oktober 2012]. Diunduh dalam: http://www.undip.ac.id.

14. Setegn T, Gerbabu M. Belachew T. Determinants of timely initiation of breastfeeding among mothers in Goba Woreda, South East Ethiopia: a cross sectional study. BMC Public Health [serial on internet]. 2011 Apr [cited 2012 Aug 18]; 11: 217. Available from: www.ncbi.nlm.nih.gov /pubmed/21473791.

15. Nelvi. Analisis sosialisasi program inisiasi menyusu dini (IMD) dan ASI eksklusif kepada bidan di Kabupaten Klaten. 2004 [diakses tanggal 30 Maret 2013]. Diunduh dari: http.pasca.unhas.ac.id.

16. Anita. Inisiasi Menyusu Dini dan pemberian air susu ibu ekslusif di Kecamatan Johan Pahlawan Kabupaten Aceh Barat. 2008 [diakses tanggal 13 Juni 2012]. Diunduh dari: www.researchgate.net

17. Tawiah AC, Kirkwood BR, Edmond K, Bazzano A, Hill Z. Early initiation of beastfeeding in Ghana: barriers and facilitators, Journal of Perinatology. 2008; 28, S46-S52.

18. Himani, Kaur B, Kumar P. Effect of initiation of breastfeeding within one hour of delivery on maternal infant bonding. Nursing and Midwifery Research Journal. 2011; 7(3). 